\title{
Prediction of Surface Product Quality and Operation Reliability of Grinding Machines
}

Imrich Lukovics, Jiř́ Čop, Ladislav Fojtl, Petr Lukovics, Vladimír Pata

Faculty of Technology, Tomas Bata University in Zln, Nad Stráněmi 4511, 76005 Zlín, Czech Republic. E-mail: lukovics@ft.utb.cz,cop@ft.utb.cz,fojtl@ft.utb.cz,pata@ft.utb.cz,

High quality products require modern and precise production machines, technologies and quality equipment of industrial metrology. Research paper discusses the possibility of vibration detection at production machines because of process conditions changes. Furthermore, paper also provides a methodology for assessment of vibration amplitude using non-contact laser interferometer, which uses Michelson principle for evaluation. Paper also provides information about a method of vibration amplitude evaluation by contact method using a piezoelectric vibration sensor connected to Balantron 2001 device. The effect of technological conditions on the quality of functional areas expressed by the arithmetic average roughness is experimentally and statistically determined. Experimental study also evaluates the influence of technological conditions during surface grinding on the amplitude of vibration of grinding spindle and provides a correlation between the vibration amplitude of grinding machine and product quality. Moreover, the change of vibration amplitude during three years of production is observed and production capabilities and accuracy of the machine during five years of manufacturing were predicted.

Keywords: Vibration, Grinding, Surface quality, Roughness

\section{Acknowledgement}

This study was supported by the internal grant of TBU in Zlín No. IGA/FT/2014/003 funded from the resources of specific university research.

\section{References}

[1] BÍLEK, O., LUKOVICS, I. Model of Dynamics within Highspeed Grinding Process. In DUSE, D.M. ; BRINDASU, P.D.; BEJU, L.D. (eds.). MSE 2009: Proceedings of the Manufacturing Science and Education. Sibiu, Romania, June 4-6. Sibiu: Lucian Blaga University of Sibiu, 2009, p. 11-14. ISSN 1843-2522.

[2] HOLEŠOVSKÝ, F., NOVÁK, M., MICHNA, Š. Studium změn broušené povrchové vrstvy při dynamickém zatěžování. Strojírenská technologie. s. 73-76. ISSN 1211-4162.

[3] JERSÁK, J. Vliv dynamického vyvážení brousícího kotouče na drsnost povrchu obrobených součástí. Strojírenská technologie. 2012, roč. 16, s. 27-33. ISSN 1213-2489.

[4] KUNDRÁK, J. Alternative machining procedures of hardened steels. Manufacturing technology. 2011, vol 11, no. 11., pp. 3239, ISSN 1213-2489.

[5] KUNDRAK, J., MAMALIS, A. G., GYANI, K., BANA, V. Surface layer microhardness changes with high-speed, The International Journal of Advanced Manufacturing Technology. Volume 53, Issue 1-4 (2011), pp.105-112 DOI: 10.1007/s00170$010-2840-\mathrm{y}$

[6] LUKOVICS, I., BÍLEK, O. High Speed Grinding Process. Manufacturing Technology, 2008, 8, 12-18. ISSN $1213248-9$.

[7] LUKOVICS, I., BÍLEK, O., HOLEMÝ, S. Development of Grinding Wheels for Tools Manufacturing. Manufacturing Technology, 2010, No.10, p.10-16. ISSN 1213-2489

[8] LUKOVICS, I., ČOP, J., LUKOVICS, P., SENÁLEK, S. Hodnocení kmitání technologických zařízení. Strojírenská technologie XVIII, no. 4 (2013). str. 254-258. ISSN 1211-4162.

[9] LUKOVICS, I., ROKYTA, L. Influence of the Technological Conditions on Quality by Grinding. Strojírenská technologie, 2010, roč. 14, s. 151-154. ISSN 1211-4162

[10] LUKOVICS, P. Vliv vibrací brousicího nástroje na strukturu broušeného povrchu. Zlín, 2013. Disertační práce. Vysoké učení technické v Brně. Fakulta strojního inženýrství. UVSSR

[11] MÁDL, J. Surface Properties in Precize and Hard Machining. Manufacturing Technology. 2012, č. 13. ISSN $1213-2489$.

[12] NOVÁK, M. a R. DOLEŽAL. G-Ratio in hardened steel grinding with differentes coolant. Manufacturing Technology. 2012, roč. 13, p. 192 - 197. ISSN 1213-2489.

[13] NOVÁK, P., MÁDL, J. Effective Evaluation of Measured Dynamic Values of Cutting Forces and Torques. Manufacturing Technology, vol. I, 2001, pp 56-62, ISSN 1213248-9. 